\title{
New production in the central equatorial Pacific
}

\author{
M. Angélica Peña ${ }^{1}$, W. Glen Harrison ${ }^{2}$, Marlon R. Lewis ${ }^{1}$ \\ ${ }^{1}$ Department of Oceanography, Dalhousie University, Halifax, Nova Scotia, B3H 4J1 Canada \\ ${ }^{2}$ Department of Fisheries and Oceans, Biological Oceanography Division, Bedford Institute of Oceanography, Box 1006 , \\ Dartmouth, B2Y 4A2 Canada
}

\begin{abstract}
Uptake rates of nitrogen $\left({ }^{15} \mathrm{NO}_{3}{ }^{-}\right.$and $\left.{ }^{15} \mathrm{NH}_{4}{ }^{+}\right)$and primary productivity were measured along a transect across the equatorial Pacific region at ca $135^{\circ} \mathrm{W}$ from $15^{\circ} \mathrm{S}$ to $15^{\circ} \mathrm{N}$, in April 1988 Latitudinally, higher rates of total and new production (i.e. the production resulting from $\mathrm{NO}_{3}{ }^{-}$uptake) were observed near the equator coinciding with higher concentrations of chl a and $\mathrm{NO}_{3}{ }^{-}$Despite significant variation in $\mathrm{NO}_{3}{ }^{-}$concentration, variability of phytoplankton biomass and production was low along the transect. Vertically, $\mathrm{NO}_{3}{ }^{-}$uptake rates tended to increase with depth in the euphotic zone following the increase in $\mathrm{NO}_{3}{ }^{-}$concentration. Between $6^{\circ} \mathrm{S}$ and $4^{\circ} \mathrm{N}$, where $\mathrm{NO}_{3}{ }^{-}$was abundant, the average euphotic zone integrated $f$-ratio $\left(\mathrm{NO}_{3}{ }^{-}\right.$uptake $\times 6.6$ /primary productivity) was 0.39 . North and south of this region, where $\mathrm{NO}_{3}{ }^{-}$was low or undetectable, a lower mean $f$-ratio was found $(0.22$ and 0.09 , respectively). Despite $\mathrm{NO}_{3}{ }^{-}$abundance at the equator, regenerated $\mathrm{N}$ was the major source of inorganic $\mathrm{N}$ used by phytoplankton. Low utilization of available $\mathrm{NO}_{3}{ }^{-}$was likely the consequence of grazing effects. A high grazing pressure in the equatorial Pacific region would reduce the absolute $N$ consumption by reducing phytoplankton biomass, and also would increase the availability of regenerated $\mathrm{N}$ (i.e. $\mathrm{NH}_{4}{ }^{+}$). Since $\mathrm{NH}_{4}{ }^{+}$is generally the preferred form of $\mathrm{N}$ used by phytoplankton, its availability may be an important regulator of new production in this nitrate-rich environment.
\end{abstract}

\section{INTRODUCTION}

In much of the ocean, phytoplankton production seems to be constrained by $N$ availability in the euphotic zone. Nitrogen for phytoplankton utilization comes from 2 sources: $\mathrm{N}$ regenerated (mostly $\mathrm{NH}_{4}{ }^{+}$) in the euphotic zone through food web metabolism, and $\mathrm{N}$ from outside the euphotic zone (mostly $\mathrm{NO}_{3}{ }^{-}$) supplied mainly by vertical fluxes. Primary production has been distinguished as regenerated or new production according to which of these $\mathrm{N}$ sources is being used by phytoplankton (Dugdale \& Goering 1967). In specific regions of the world ocean (i.e. equatorial Pacific, Northeast Pacific, Southern Ocean), phytoplankton production and biomass are much lower than would be expected from the observed high concentrations of plant nutrients found in the surface layer. This anomalous condition has been called high nutrient-low chlorophyll (HNLC) situation (Minas et al. 1986).

In the equatorial Pacific, surface concentrations of plant nutrients are elevated due to quasi-stationary upwelling associated with equatorial divergence (Cromwell 1953, Knauss 1963, Wyrtki 1981). It has been estimated that complete utilization of the $\mathrm{NO}_{3}{ }^{-}$ upwelled in this region by phytoplankton cells could account for a significant proportion (23 to $56 \%$ ) of the global new production (Chavez \& Barber 1987) and, hence, a comparable downward flux of organic matter to the ocean interior (Eppley \& Peterson 1979). Few studies of $N$ utilization by phytoplankton have been done in the equatorial Pacific. Recently, results from ${ }^{15} \mathrm{~N}$ uptake studies have shown an average $f$-ratio $\left(\mathrm{NO}_{3}{ }^{-}\right.$uptake/total-N uptake; as defined by Eppley \& Peterson 1979) of 0.17 in the equatorial Pacific region at $150^{\circ} \mathrm{W}$ (Dugdale et al. 1992) and similar low values ( $f$-ratios 0.1 to 0.3 ) in the eastern equatorial Pacific (Murray et al. 1989). These studies showed that, although $\mathrm{NO}_{3}^{-}$was the dominant form of $\mathrm{N}$ in the environment, most of the production was fuelled by regenerated forms of nitrogen. In contrast, Eppley \& Renger (1992), using time course measurements of $\mathrm{NO}_{3}{ }^{-}$concentrations, observed $\mathrm{NO}_{3}{ }^{-}$ removal from the medium at rates far in excess of those determined by ${ }^{15} \mathrm{~N}$-nitrate incorporation and, when converted to carbon (using a $6.6 \mathrm{C} / \mathrm{N}$ molar ratio), were equivalent to the total primary production in the equatorial Pacific at $150^{\circ} \mathrm{W}$, implying an $f$-ratio $\sim 1.0$. 
It has recently been suggested (Wilkerson \& Dugdale 1992) that phytoplankton in the equatorial Pacific upwelling region are not able to effectively utilize the available $\mathrm{NO}_{3}{ }^{-}$because initial concentrations are below some 'physiological threshold' necessary to induce maximal $\mathrm{NO}_{3}{ }^{-}$uptake rates as often observed in coastal upwelling regions (e.g. MacIsaac et al. 1985, Wilkerson \& Dugdale 1987). On the other hand, Murray et al. (1989) suggested that $\mathrm{NH}_{4}{ }^{+}$concentration may be controlling nitrate utilization since a small relative increase in $\mathrm{NH}_{4}{ }^{+}$appeared to result in a dramatic reduction in the $f$-ratio. Wheeler \& Kokkinakis (1990) have offered a similar explanation for persistence of residual $\mathrm{NO}_{3}{ }^{-}$in the northeast Pacific surface waters. Martin et al. (1989), taking a different approach, have suggested that the availability of $\mathrm{Fe}$ in the equatorial Pacific region is inadequate to support productivity rates expected based on the high $\mathrm{NO}_{3}{ }^{-}$ concentrations. In this regard also, Price et al. (1991) have recently shown a clear link between Fe availability and nitrate-based production. Several other studies in the equatorial upwelling region (Walsh 1976, Thomas 1979, Murray et al. 1989, Peña et al. 1990, Cullen et al. 1992) have suggested that grazing controls phytopiankton biomass and productivity. The relatively stable nature of these systems seems to have favored a close coupling between rates of phytoplankton growth and zooplankton grazing and excretion.

In this study, measurements of ${ }^{15} \mathrm{~N}$-labelled nitrogen incorporation into particulate matter and primary productivity along a transect across the equatorial Pacific at $135^{\circ} \mathrm{W}$, has led to the conclusion that the 'anomously low' new production $\left(\mathrm{NO}_{3}{ }^{-}\right.$uptake) in this region may result from grazing and concomitant $\mathrm{NH}_{4}{ }^{+}$ production and utilization by the phytoplankton.

\section{METHODS}

Samples were collected aboard the RV 'Wecoma' (Cruise W8803-B) on a transect across the equatorial Pacific region within a few degrees of $135^{\circ} \mathrm{W}$ longitude from ca $15^{\circ} \mathrm{S}$ to $15^{\circ} \mathrm{N}$ in April 1988. At 13 stations along this transect (see Table 1), water samples were collected in the euphotic zone (between 0 and $120 \mathrm{~m}$ ) using twelve 51 Niskin bottles mounted on a rosette sampling system equipped with a CTD. The Niskin bottles had been retrofitted with silicon O-ring and silicon tubing as the closing mechanism (Price et al. 1986).

Samples for nutrients $\left(\mathrm{NO}_{3}{ }^{-}\right.$and silicate) concentration were taken from 12 fixed depths at each station (between 0 and $200 \mathrm{~m}$ ) and determined by the method described by Strickland \& Parsons (1972) with an autoanalyser. Light penetration and the euphotic depth conventionally defined as the $1 \%$ light intensity was determined by Secchi disk lowering $(1 \%$ light level = 3 times the Secchi depth).

Uptake rates of $\mathrm{NO}_{3}{ }^{-}$and $\mathrm{NH}_{4}{ }^{+}$were measured by incorporation of ${ }^{15} \mathrm{~N}$ at 4 to 6 depths. Water samples of 1 or 2 l were incubated on deck in polycarbonate bottles which were inoculated with either ${ }^{15} \mathrm{NH}_{4} \mathrm{Cl}$ or $\mathrm{Na}^{15} \mathrm{NO}_{3}\left(99.0\right.$ at. $\left.\%{ }^{15} \mathrm{~N}\right)$ such that added ${ }^{15} \mathrm{NH}_{4}{ }^{+}$concentrations were $0.05 \mathrm{mmol} \mathrm{m}^{-3}$ and ${ }^{15} \mathrm{NO}_{3}{ }^{-}$concentrations were $0.5 \mathrm{mmol} \mathrm{m}{ }^{-3} \cdot{ }^{15} \mathrm{NO}_{3}^{-}$enrichments were $>10 \%$ of ambient concentrations in the surface layer except in the $\mathrm{NO}_{3}{ }^{-}$abundant stations (Stns 20 to 60 ) where they were $\sim 10 \%$. Neutral density screens were used to approximate the light attenuation at the depth from which the samples were drawn. Samples were incubated between dawn and local noon, except at Stn 4 where incubation took place in the afternoon, and lasted for no more than $6 \mathrm{~h}$ in order to minimize isotope dilution effects due to $\mathrm{NH}_{4}{ }^{+}$recycling (Glibert et al. 1982a) and to overcome the possible bias introduced by initial 'surge' uptake (Dugdale \& Wilkerson 1986). $\mathrm{NH}_{4}{ }^{+}$uptake rates were not corrected for isotope dilution, since it has been shown that the error should be relatively small in open ocean waters (Kanda et al. 1987). At the end of the incubation period, samples were filtered onto precombusted Whatman GF/F glass fiber filters, which were then frozen and transported back to the lab. After oven-drying the filters, the ${ }^{15} \mathrm{~N}$-enrichment of the particulate matter was determined using the micro-Dumas combustion technique and analysis by emission spectrometry (Fiedler \& Proksch 1975, Harrison 1983). Uptake rates are reported as $\mu \mathrm{mol} \mathrm{N} \mathrm{m}^{-3} \mathrm{~h}^{-1}$ computed by multiplying the specific uptake rates, $\mathrm{V}\left(\mathrm{h}^{-1}\right)$, by the particulate organic nitrogen (PON) concentration of the sample determined at the beginning of the incubation (Dugdale \& Goering 1967). $\mathrm{NH}_{4}{ }^{+}$uptake rates were calculated based on the expected range of substrate concentrations, since $\mathrm{NH}_{4}{ }^{+}$levels were not directly measured in this study. The values chosen were 0.01 mmol m $\mathrm{m}^{-3}$, corresponding to the lower concentration range observed in open ocean waters (Brzezinski 1988), and the values $\left(0.12\right.$ and $\left.0.15 \mathrm{mmol} \mathrm{m}^{-3}\right)$ found by Dugdale et al. (1992) along a transect similar to ours across the equatorial Pacific region at $150^{\circ} \mathrm{W}$ i the 2 values represent average concentrations outside and within the equatorial zone, respectively. Integrated daily $\mathrm{N}$ uptake rates were computed by multiplying hourly rates by 24 (Harrison et al. 1992).

Primary productivity was determined in duplicate at 4 depths (between 0 and $120 \mathrm{~m}$ ) by measuring the uptake of ${ }^{14} \mathrm{C}$-bicarbonate in samples incubated in $125 \mathrm{ml}$ pyrex bottles. As with ${ }^{15} \mathrm{~N}$ uptake experiments, samples were incubated in simulated in situ incubators over $6 \mathrm{~h}$. Incubations were ended by filtering the 
Table 1. Location, depth of the euphotic zone $\left(Z_{e u}\right)$ and surface nutrient (nitrate and silicate) concentration at each station occupied

\begin{tabular}{|c|c|c|c|c|c|}
\hline $\begin{array}{l}\text { Station } \\
\text { no. }\end{array}$ & Latitude & Longitude (W) & $\begin{array}{l}z_{e u} \\
(m)\end{array}$ & $\begin{array}{c}\text { Nitrate } \\
\left(\mathrm{mmol} \mathrm{m}^{-3}\right)\end{array}$ & $\begin{array}{c}\text { Silicate } \\
\left(\mathrm{mmol} \mathrm{m}^{-3}\right)\end{array}$ \\
\hline 4 & $14^{\circ} 56.4^{\prime} \mathrm{S}$ & $133^{\circ} 54.6^{\prime}$ & 120 & 0 & 1.2 \\
\hline 11 & $12^{\circ} 09.4^{\prime} \mathrm{S}$ & $134^{\circ} 19.5^{\prime}$ & 105 & 0.3 & 1.3 \\
\hline 20 & $5^{\circ} 58.0^{\prime} \mathrm{S}$ & $134^{\circ} 59.4^{\prime}$ & 81 & 4.7 & 2.6 \\
\hline 34 & $1^{\circ} 59.9^{\prime} \mathrm{S}$ & $133^{\circ} 00.2^{\prime}$ & 87 & 4.5 & 0.6 \\
\hline 39 & $0^{\circ} 59.9^{\prime} \mathrm{S}$ & $133^{\circ} 35.5^{\prime}$ & 69 & 4.5 & 0.9 \\
\hline 50 & $0^{\circ} 30.8^{\prime} \mathrm{N}$ & $133^{\circ} 188^{\prime}$ & 63 & 5.3 & 1.9 \\
\hline 55 & $2^{\circ} 0.30^{\prime} \mathrm{N}$ & $133^{\circ} 37.9^{\prime}$ & 72 & 5.1 & 1.1 \\
\hline 60 & $4^{\circ} 17.2^{\prime} \mathrm{N}$ & $133^{\circ} 30.5^{\prime}$ & 75 & 0.4 & 0.8 \\
\hline 65 & $5^{\circ} 45.1^{\prime} \mathrm{N}$ & $135^{\circ} 00.0^{\prime}$ & 78 & 0.9 & 2.1 \\
\hline 73 & $7^{\circ} 13.7^{\prime} \mathrm{N}$ & $137^{\circ} 33.3^{\prime}$ & 81 & 0.2 & 1.8 \\
\hline 78 & $9^{\circ} 03.4^{\prime} \mathrm{N}$ & $136^{\circ} 47.5^{\prime}$ & 81 & 0.2 & 1.8 \\
\hline 88 & $11^{\circ} 05.2^{\prime} \mathrm{N}$ & $136^{\circ} 26.8^{\prime}$ & 84 & 0.1 & 1.8 \\
\hline 96 & $15^{\circ} 40.9^{\prime} \mathrm{N}$ & $143^{\circ} 05.7^{\prime}$ & 120 & 0 & 1.6 \\
\hline
\end{tabular}

sample through a Whatman GF/F filter and rinsing with $0.01 \mathrm{~N} \mathrm{HCl}$. Correction for abiotic uptake was made with 1 'time-zero' control bottle from each depth. Total added radioactivity in each sample was determined by adding $50 \mu \mathrm{l}$ of water from the incubation bottle to a scintillation vial containing $10 \mathrm{ml}$ of scintillation cocktail. ${ }^{14} \mathrm{C}$ activity was determined by scintillation spectrometry and carbon uptake estimated by the method of Steemann Nielsen (1952). To estimate daily primary production, integrated hourly primary production rates were multiplied by 12 to estimate photoperiod production and the values in turn were reduced by $15 \%$ to approximate dark respiration losses (Steemann Nielsen \& Hansen 1959).

Chl a concentrations, corrected for phaeopigment, were measured fluorometrically (Holm-Hansen et al. $1965)$ at 6 depths. Duplicate water samples $(100 \mathrm{ml})$ were filtered through Whatman GF/F filters and then extracted with $90 \%$ acetone in the dark at $-20{ }^{\circ} \mathrm{C}$ for $24 \mathrm{~h}$. The fluorescence was measured with a Turner Design fluorometer previously calibrated against pure chl a (Sigma). For total PON, duplicate 1 l samples were passed through combusted $\mathrm{GF} / \mathrm{F}$ filters and stored at $-20^{\circ} \mathrm{C}$; they were later dried at $60^{\circ} \mathrm{C}$ and analysed with a Perkin Elmer elemental analyser (model 2400) calibrated with a cyclohexanone standard.

\section{RESULTS}

Vertical sections of temperature, $\mathrm{NO}_{3}{ }^{-}$, chl a, PON and $\mathrm{NO}_{3}^{-}$uptake rates are shown in Fig. 1. The latitudinal distribution of surface temperature and $\mathrm{NO}_{3}{ }^{-}$ showed a marked horizontal gradient, with a decrease in temperatures and an increase in $\mathrm{NO}_{3}{ }^{-}$concentration around the equator, indicating upwelling at the equa- torial divergence. $\mathrm{NO}_{3}{ }^{-}$concentrations in the upper layer were $>4 \mathrm{mmol} \mathrm{m} \mathrm{m}^{-3}$ between $6^{\circ} \mathrm{S}$ and $3^{\circ} \mathrm{N}$ and decreased poleward; low temperature values $\left(<26^{\circ} \mathrm{C}\right)$ were in a narrower band $\left(-3^{\circ} \mathrm{S}\right.$ to $\left.3^{\circ} \mathrm{N}\right)$. Vertically, $\mathrm{NO}_{3}{ }^{-}$concentrations increased with depth north of $6^{\circ} \mathrm{S}$, but to the south no vertical gradient in the upper $120 \mathrm{~m}$ (euphotic zone; see Table 1) was found. In contrast to the marked gradient of $\mathrm{NO}_{3}{ }^{-}$concentrations, chl a concentrations were low and relatively constant along the transect. Higher concentrations $\left(0.5 \mathrm{mg} \mathrm{m}^{-3}\right)$ were found at subsurface depths near the equator and lower values $\left(<0.2 \mathrm{mg} \mathrm{m}^{-3}\right)$ towards the south. Along the transect, PON concentrations showed a different pattern from that of chl $a_{\text {; }}$ its highest values $>1 \mathrm{mmol}$ $\mathrm{m}^{-3}$ ) were found in the surface layer near the equator and at subsurface depths around $12^{\circ} \mathrm{S}$. These differing distributions of chl a and PON suggested, as previously reported (Peña et al. 1991), that non-phytoplanktonic particles were abundant along this transect. In general, $\mathrm{NO}_{3}{ }^{-}$uptake rates showed a similar distribution to that of $\mathrm{NO}_{3}^{-}$concentrations. Uptake rates in the upper layer were higher in the equatorial region (maximum $1.6 \mu \mathrm{mol} \mathrm{N} \mathrm{m}^{-3} \mathrm{~h}^{-1}$ at $2^{\circ} \mathrm{N}$ ) and tended to increase with depth where $\mathrm{NO}_{3}^{-}$concentrations also increased. Whereas surface layer $\mathrm{NO}_{3}{ }^{-}$concentrations varied by greater than 50-fold along the transect, the $\mathrm{NO}_{3}{ }^{-}$ uptake rates were less variable $(\sim 10$-fold).

Along the transect, $\mathrm{NO}_{3}{ }^{-}$and silicate concentrations showed a different pattern (Table 1). Surface $\mathrm{NO}_{3}^{-}$ concentrations ranged from undetectable $(<0.05 \mathrm{mmol}$ $\mathrm{m}^{-3}$ ) to $5.3 \mathrm{mmol} \mathrm{m}^{-3}$, whereas surface silicate concentrations were always detectable and less variable (range 0.6 to $2.6 \mathrm{mmol} \mathrm{m}^{-3}$ ). Stations were subdivided into 3 groups according to $\mathrm{NO}_{3}{ }^{-}$concentration (Peña et al. 1990): (1) stations south of the equator where $\mathrm{NO}_{3}^{-}$ was low $\left(<0.3 \mathrm{mmol} \mathrm{m}^{-3}\right.$ ) or undetectable throughout the euphotic zone (Stns $4 \& 11$ ); (2) stations in the equa- 

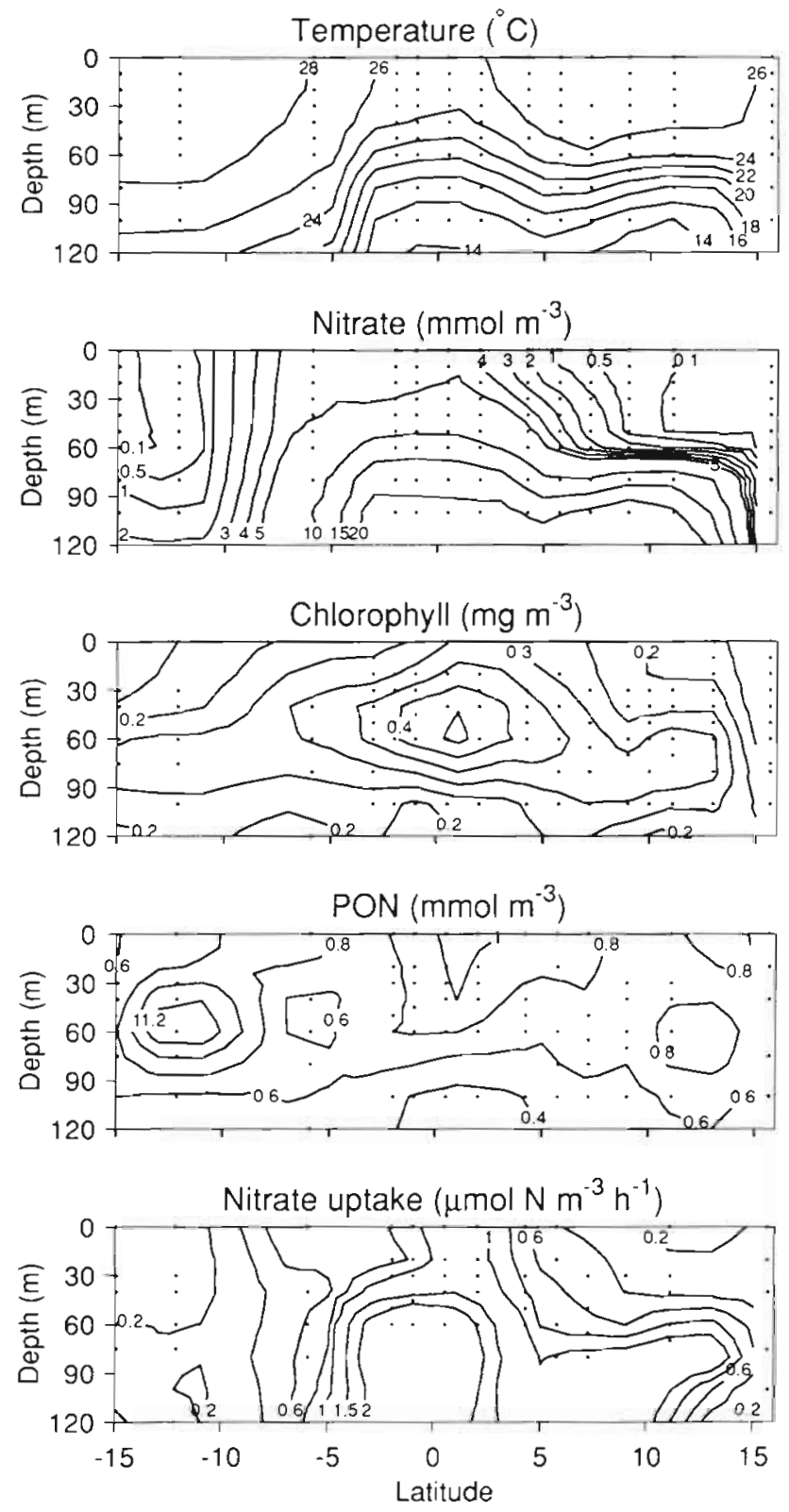

Fig. 1. Vertical sections of temperature, nitrate, chl a, PON, and nitrate uptake along the cruise track. Longitudinal variations between stations were ignored. Negative latitudes are south

torial region where $\mathrm{NO}_{3}{ }^{-}$was abundant $\left(>4 \mathrm{mmol} \mathrm{m}^{-3}\right.$ ) in the euphotic zone (Stns 20 to 55); and (3) stations north of the equator where $\mathrm{NO}_{3}{ }^{-}$concentrations were intermediate between the other groups (undetectable to $<1 \mathrm{mmol} \mathrm{m}^{-3}$ ) in the upper layer but where a strong nitracline existed near the bottom of the euphotic zone (Stns 60 to 96).

The integrated values of chl a, primary production and $\mathrm{N}$ uptake over the euphotic zone for each station and region are summarized in Table 2. The highest $\mathrm{NO}_{3}$ uptake rate (3.48 mmol $\mathrm{N} \mathrm{m}^{-2} \mathrm{~d}^{-1}$ ) was found at $1^{\circ} \mathrm{S}$, coinciding with the highest chl a concentration $\left(27.4 \mathrm{mg} \mathrm{m}^{-2}\right)$ and primary productivity $(86.1 \mathrm{mmol}$ $C \mathrm{~m}^{-2} \mathrm{~d}^{-1}$ ). Despite the relatively constant concentrations of chl a along the transect (range 15.1 to $27.9 \mathrm{mg} \mathrm{m}^{-2}$ ), however, integrated primary production and new production varied 5-fold (range 16.7 to 86.1 mmol C m $\mathrm{C}^{-2} \mathrm{~d}^{-1}$ ) and 9 -fold (range 0.38 to $3.48 \mathrm{mmol}$ $\mathrm{N} \mathrm{m} \mathrm{m}^{-2} \mathrm{~d}^{-1}$ ), respectively. Regionally, the highest mean integrated values of chl a, primary production, and $\mathrm{NO}_{3}{ }^{-}$uptake were observed in the equatorial region. South of the equator, integrated chl a and primary production were similar to those north of the equator, but $\mathrm{NO}_{3}{ }^{-}$uptake rates were significantly lower. Estimates of $\mathrm{NH}_{4}{ }^{+}$uptake rates ranged from 0.34 to $51.47 \mathrm{mmol}$ $\mathrm{N} \mathrm{m}^{-2} \mathrm{~d}^{-1}$ and, except by the stations between $2^{\circ} \mathrm{S}$ and $2^{\circ} \mathrm{N}$, exceeded $\mathrm{NO}_{3}{ }^{-}$uptake regardless of the assumed ambient $\mathrm{NH}_{4}{ }^{+}$concentration (Table 2). If $\mathrm{NH}_{4}{ }^{+}$levels observed during the $150^{\circ} \mathrm{W}$ study of Dugdale et al. (1992) were typical also for $135^{\circ} \mathrm{W}$, then $\mathrm{NH}_{4}{ }^{+}$uptake averaged from 82 to $96 \%$ of the total $\left(\mathrm{NO}_{3}{ }^{-}\right.$plus $\left.\mathrm{NH}_{4}{ }^{+}\right)$uptake, the lower value representing the equatorial region

F-ratios (Table 2) were calculated as the ratio of integrated $\mathrm{NO}_{3}{ }^{-}$uptake (converted to $\mathrm{C}$ using a $6.6 \mathrm{C} / \mathrm{N}$ molar ratio) and integrated primary production measured as ${ }^{14} \mathrm{C}$ uptake and not by the conventional method of Eppley \& Peterson (1979), i.e. $\mathrm{NO}_{3}{ }^{-}$uptake/ total- $\mathrm{N}$ uptake, since accurate estimates of $\mathrm{NH}_{4}{ }^{+}$ uptake could not be made. F-ratios calculated in this manner were lower than 0.4 along the transect. The only exception occurred at $2^{\circ} \mathrm{S}$ (Stn 34) where a high f-ratio (0.85) was observed, resulting from low primary production rather than high new production. Among the 3 regions, the average $f$-ratio north of the equator (0.22) and south of the equator $(0.09)$ were 2 to 4 times lower than that in the equatorial region (0.39).

The mean vertical profile of $\mathrm{NO}_{3}^{-}$uptake and the rate normalized to $\mathrm{chl} a$ in the 3 regions is shown in Fig. 2. Absolute $\mathrm{NO}_{3}{ }^{-}$uptake rates were higher in the equatorial region than the other regions at all depths sampled. In this region, higher uptake rates were found at subsurface depths (maximum $2.7 \mu \mathrm{mol} \mathrm{N}$ $\mathrm{m}^{-3} \mathrm{~h}^{-1}$ at $60 \mathrm{~m}$ ) compared with the upper $40 \mathrm{~m}$ (avg. $1.1 \mu \mathrm{mol} \mathrm{N} \mathrm{m}^{-3} \mathrm{~h}^{-1}$ ). A subsurface increase in $\mathrm{NO}_{3}$ uptake approximately 3 times the mean value of the upper $60 \mathrm{~m}\left(1.3 \mu \mathrm{mol} \mathrm{N} \mathrm{m}^{-3} \mathrm{~h}^{-1}\right.$ at $80 \mathrm{~m}$ compared with 0.43 ) was also observed north of the equator. South of the equator, where a nutricline was absent in the euphotic zone, the values were low (range 0.1 to $0.52 \mu \mathrm{mol} \mathrm{N} \mathrm{m}^{-3} \mathrm{~h}^{-1}$ ) and remained relatively constant with depth. Chl a-normalized uptake rates showed a similar vertical pattern in each region; highest values were observed at subsurface depths rather than in the 
Table 2. Chl a, primary productivity, and nitrogen uptake integrated over the euphotic zone. Ammonium uptake rates were calculated based on the expected range of substrate concentration $\left(0.01\right.$ to $0.15 \mathrm{mmol} \mathrm{m}^{-3}$ at the equatorial region and 0.01 to $0.12 \mathrm{mmol} \mathrm{m} \mathrm{m}^{-3}$ at other regions). Means and coefficients of variation ( $\mathrm{CV}=$ standard deviation divided by mean and expressed as percentage) computed for each region (see text for regional designation)

\begin{tabular}{|c|c|c|c|c|c|}
\hline $\begin{array}{c}\text { Station } \\
\text { no. }\end{array}$ & $\begin{array}{c}\text { Chl } a \\
\left(\mathrm{mg} \mathrm{m}^{-2}\right)\end{array}$ & $\begin{array}{c}\text { Primary } \\
\text { productivity } \\
\left(\mathrm{mmol} \mathrm{C} \mathrm{m}^{-2} \mathrm{~d}^{-1}\right)\end{array}$ & $\begin{array}{c}\mathrm{NO}_{3}^{-} \\
\text {uptake } \\
\left(\mathrm{mmol} \mathrm{N} \mathrm{m} \mathrm{m}^{-2} \mathrm{~d}^{-1}\right)\end{array}$ & $\begin{array}{c}\mathrm{NH}_{4}^{+} \\
\text {uptake } \\
\left.\text { (mmol } \mathrm{N} \mathrm{m}^{-2} \mathrm{~d}^{-1}\right)\end{array}$ & $f$-ratio \\
\hline \multicolumn{6}{|c|}{ South of the Equator } \\
\hline 4 & 18.7 & 38.4 & 0.75 & $2.80-22.83$ & 0.13 \\
\hline 11 & 22.4 & 47.4 & 0.38 & $1.63-14.12$ & 0.05 \\
\hline Mean & 20.6 & 42.9 & 0.56 & $2.22-18.47$ & 0.09 \\
\hline $\mathrm{CV}$ & 9.0 & 10.5 & 32.5 & $26.5-23.6$ & 44.4 \\
\hline \multicolumn{6}{|c|}{ Equatorial region } \\
\hline 20 & 22.1 & 32.2 & 1.15 & $1.22-12.99$ & 0.24 \\
\hline 34 & 24.3 & 20.8 & 2.64 & $0.53-5.64$ & 0.84 \\
\hline 39 & 27.4 & 86.1 & 3.48 & $0.34-3.63$ & 0.27 \\
\hline 50 & 27.9 & 83.8 & 2.64 & $1.95-20.83$ & 0.21 \\
\hline 55 & 24.5 & 47.8 & 2.64 & $1.41-14.93$ & 0.37 \\
\hline Mean & 25.2 & 54.2 & 2.51 & $1.09-11.60$ & 0.39 \\
\hline $\mathrm{CV}$ & 8.5 & 49.1 & 30.0 & $54.0-54.1$ & 60.4 \\
\hline \multicolumn{6}{|c|}{ North of the Equator } \\
\hline 60 & 26.3 & 69.2 & 1.10 & $1.43-12.40$ & 0.11 \\
\hline 65 & 24.4 & 33.7 & 1.27 & $1.79-15.44$ & 0.25 \\
\hline 73 & 25.1 & 37.3 & 1.39 & $5.18-44.89$ & 0.24 \\
\hline 78 & 19.2 & 16.7 & 0.70 & $2.23-19.37$ & 0.28 \\
\hline 88 & 25.8 & 34.1 & 1.20 & $2.96-25.59$ & 0.23 \\
\hline 96 & 15.1 & 32.2 & 0.91 & $5.94-51.47$ & 0.19 \\
\hline Mean & 22.6 & 37.3 & 1.10 & $3.26-28.19$ & 0.22 \\
\hline $\mathrm{CV}$ & 18.3 & 42.3 & 21.1 & $52.5-52.6$ & 25.2 \\
\hline
\end{tabular}

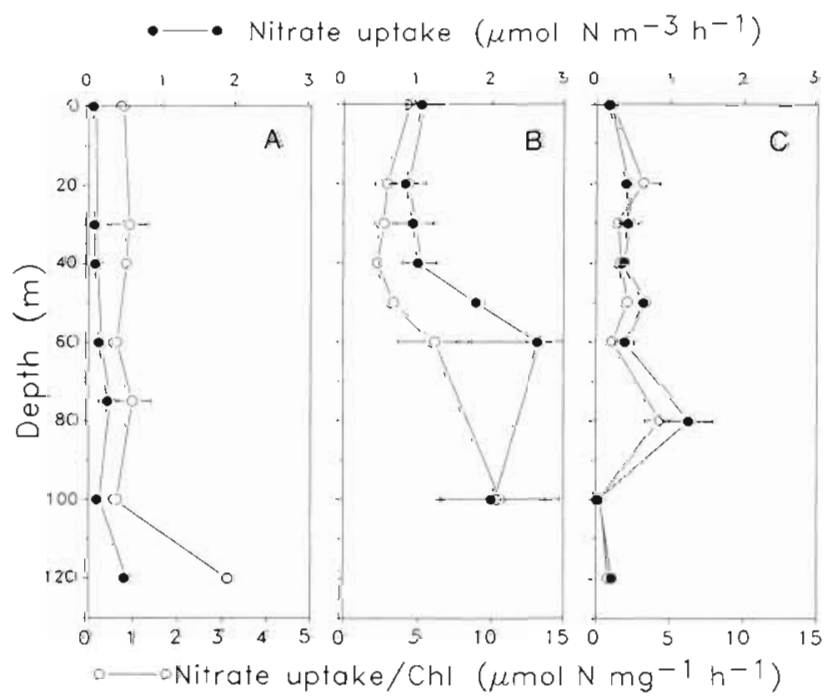

Fig. 2. Vertical profiles of nitrate uptake and nitrate uptake normalized to chl a in (A) southern, (B) equatorial and (C) northern regions. Values represent the mean rates and their standard errors upper layer. In the equatorial region, the highest normalized uptake rate was at $100 \mathrm{~m}$.

Considering all data, a significant positive correlation $\left(\mathrm{r}^{2}=0.6\right)$ was found between the chl a-normalized $\mathrm{NO}_{3}{ }^{-}$uptake rates and the ambient $\mathrm{NO}_{3}{ }^{-}$concentration (Fig. 3). A similar relationship was found between absolute $\mathrm{NO}_{3}^{-}$uptake and chl a concentration (Fig. 4).

The influence of light intensity on chl a normalized nitrate uptake was examined by comparing the different light levels experiments (Fig. 5). Although a high variation in uptake rates was observed at all light levels, a systematic light-dependence of $\mathrm{NO}_{3}{ }^{-}$uptake was not apparent. Nitrate was removed at significant rates even at the $1 \%$ level of surface light intensity.

\section{DISCUSSION}

Latitudinal distribution along this transect showed the typical increase in $\mathrm{NO}_{3}{ }^{-}$concentration at the equator associated with upwelling at the equatorial diver- 


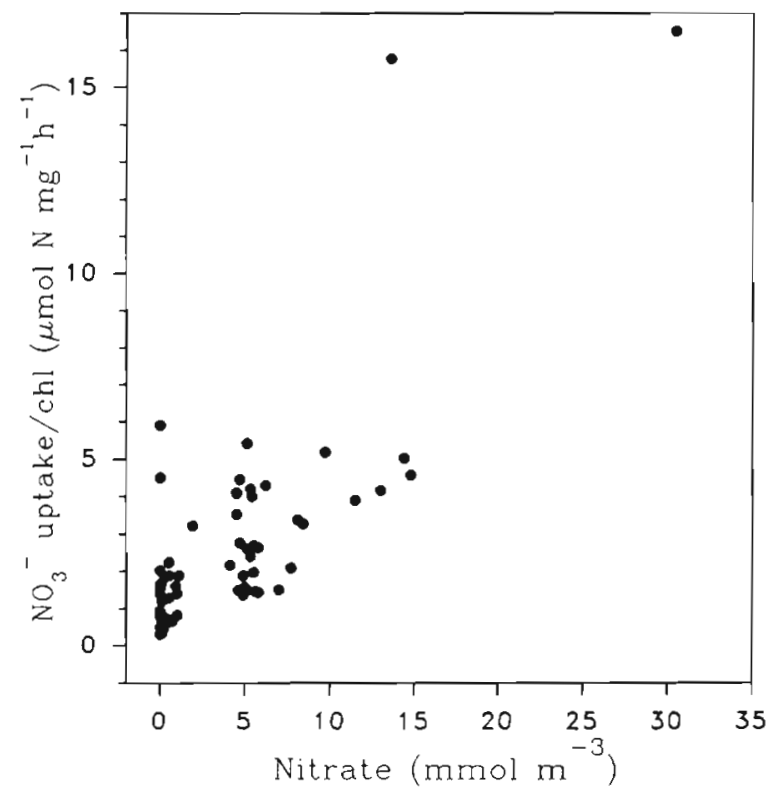

Fig. 3. Relationship between nitrate concentration and the chl a-normalized uptake rate, all data combined $\left(r^{2}=0.6\right.$, $n=64$ )

gence (Knauss 1963, Wyrtki 1981). Similarly, higher concentrations of chl $a$, primary production and new production rates were found near the equator $\left(\sim 1^{\circ} \mathrm{S}\right)$. Despite the marked gradient in surface $\mathrm{NO}_{3}{ }^{-}$concentration among the regions, however, mean integrated new production rates were regionally similar. Only south of the equator were considerably lower values observed.

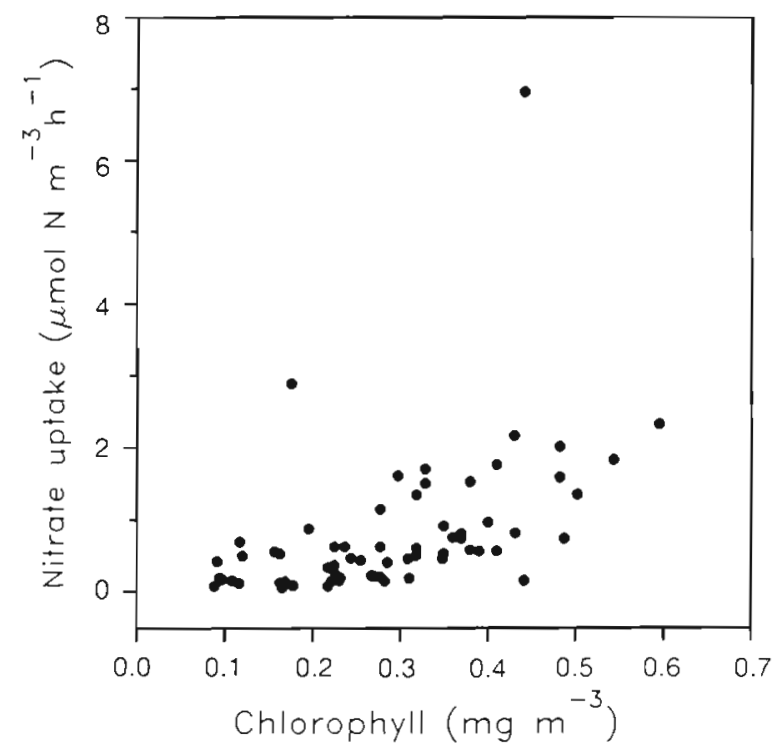

Fig. 4. Relationship between chl a concentration and nitrate uptake, all data combined $(n=64)$

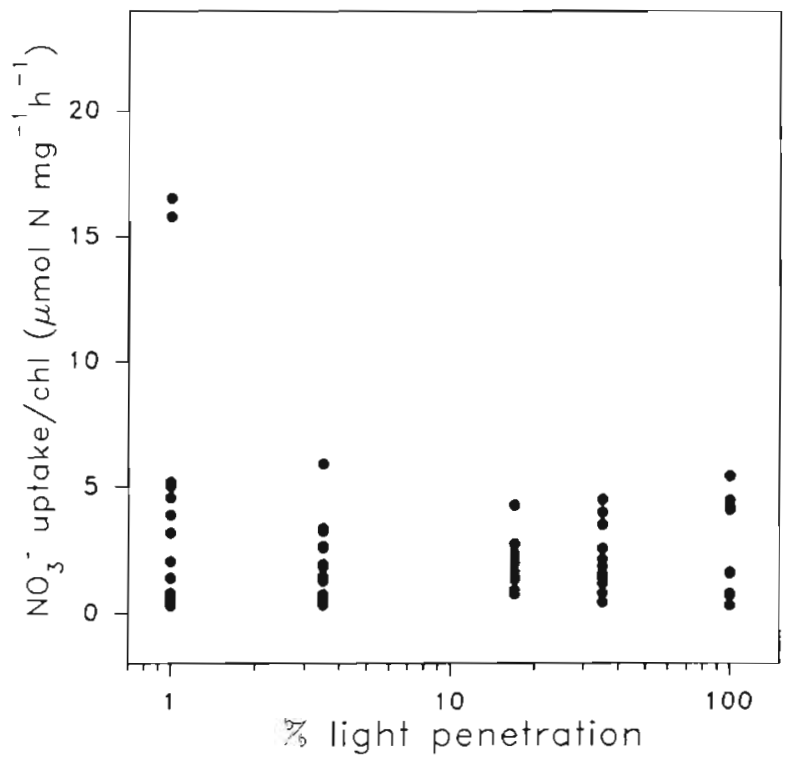

Fig. 5. Chl a-normalized nitrate uptake plotted against light level at all stations along the transect

Since phytoplankton are minor contributors to PON in this region (Peña et al. 1991, Eppley et al. 1992), the rates of $\mathrm{NO}_{3}{ }^{-}$uptake were normalized to chl a rather than to PON to facilitate regional intercomparisons. In the equatorial region, $\mathrm{NO}_{3}^{-}$uptake rates were similar to those previously found in this region (Dugdale et al. 1992) and in the range of values reported in other high nutrient-low chlorophyll environments such as the subarctic Pacific (Wheeler \& Kokkinakis 1990) and the Southern Ocean (Glibert et al. 1982b). The similarity in $\mathrm{N}$ uptake rates suggests that phytoplankton cells in the equatorial Pacific region were performing in a manner similar to that of cells found in other oceanic environments where surface $\mathrm{NO}_{3}^{-}$concentrations are comparably high.

Studies in coastal upwelling regions (MacIsaac et al. 1985, Wilkerson \& Dugdale 1987) have shown that maximum rates of phytoplankton $\mathrm{NO}_{3}{ }^{-}$uptake develop over several generation times (shift-up) due to phytoplankton physiological adaptation. The rate of shift-up appears to be related to irradiance level and the ambient concentration of $\mathrm{NO}_{3}{ }^{-}$at the time of upwelling. In the equatorial Pacific region at $150^{\circ} \mathrm{W}$, Wilkerson \& Dugdale (1992) found little or no shift-up in nitrate uptake. This led them to hypothesize that phytoplankton cells in this region are not able to completely use the available $\mathrm{NO}_{3}{ }^{-}$because $\mathrm{NO}_{3}{ }^{-}$concentrations are lower than that necessary to induce shift-up. On the other hand, it has been shown (Garside 1991) that shift-up may be an artifact of normalizing uptake rates to PON which has a time-dependent phytoplankton $\mathrm{N}$ component. In coastal upwelling 
systems, for example, the proportion of phytoplankton biomass in the PON increases with time, due in part to the exclusion of grazers during bottle incubations. In the equatorial Pacific region where much smaller phytoplankton cells dominate (Chavez 1989, Peña et al. 1990), the proportion of phytoplankton in the PON may change less since their (smaller) grazers are not as effectively removed from the incubation bottle.

Nitrogen uptake is generally thought to be lightdependent, with the uptake of $\mathrm{NO}_{3}^{-}$being more light sensitive than that of $\mathrm{NH}_{4}{ }^{+}$(e.g. Maclsaac \& Dugdale 1972). Therefore, to estimate daily $\mathrm{NO}_{3}{ }^{-}$uptake rates, hourly rates are often multiplied by 12 . Recently, however, several studies have shown significant $\mathrm{NO}_{3}{ }^{-}$ uptake at night (Glibert et al. 1982b, Cochlan et al. 1991, Harrison et al. 1992). In the central equatorial Pacific, Eppley \& Renger (1992) found disappearence of $\mathrm{NO}_{3}{ }^{-}$during night time incubations that were unexpectedly high and equal to or greater than daytime disappearance. In the present study, the light dependence of $\mathrm{NO}_{3}{ }^{-}$uptake was not investigated explicitly. However, since uptake rates of $\mathrm{NO}_{3}{ }^{-}$were not significantly diminished deep in the euphotic zone compared with the surface, our daily $\mathrm{NO}_{3}{ }^{-}$uptake rates were obtained assuming constant uptake over $24 \mathrm{~h}$. Daily uptake rates in the equatorial Pacific at $150^{\circ} \mathrm{W}$, on the other hand, were estimated assuming a $12 \mathrm{~h}$ day for $\mathrm{NO}_{3}{ }^{-}$and an $18 \mathrm{~h}$ day for $\mathrm{NH}_{4}{ }^{+}$(Dugdale et al. 1992) and in the eastern equatorial Pacific a $12 \mathrm{~h}$ and a $24 \mathrm{~h}$ day for $\mathrm{NO}_{3}{ }^{-}$and $\mathrm{NH}_{4}{ }^{+}$, respectively (Murray et al. 1989). These computational differences alone could explain the higher values of $f$-ratios found in this study compared to those previously reported (see Table 3) and point to the importance of diel studies in accurately establishing daily rates

Our $f$-ratios were estimated based on $\mathrm{NO}_{3}^{-}$uptake and total production as ${ }^{14} \mathrm{C}$ uptake instead of the traditional approach based on total $\mathrm{N}$ uptake (usually $\mathrm{NO}_{3}{ }^{-}$and $\mathrm{NH}_{4}{ }^{+}$). In the equatorial Pacific at $150^{\circ} \mathrm{W}$, similar values of $f$-ratios have been estimated by both methods (Dugdale et al. 1992). Along our $135^{\circ} \mathrm{W}$ transect, the calculated $f$-ratios were low (Table 2) indicating that regenerated $\mathrm{N}$ was the major source of inorganic- $\mathrm{N}$ used by phytoplankton. Even in the equatorial region, where $\mathrm{NO}_{3}^{-}$was abundant, the average new production represented less than $40 \%$ of the total production. Even though $\mathrm{NO}_{3}{ }^{-}$concentrations were similar within a region, $f$-ratios were variable, particularly at the equator (range 0.21 to 0.84 ). This implies that factors in addition to $\mathrm{NO}_{3}{ }^{-}$concentration are also influencing new production and the $f$-ratio. In order to compare our results with those of others working in this area, hourly rates of $\mathrm{N}$ uptake and $f$-ratio were computed (Table 3). Average $\mathrm{NO}_{3}{ }^{-}$uptake and $f$-ratio at the equator were similar to those found at $150^{\circ} \mathrm{W}$, but lower than those reported in the eastern equatorial Pacific region $\left(85^{\circ} \mathrm{W}\right)$. The opposite trend was observed for the primary production rates. Price et al. (1991) found somewhat higher $f$-ratios in a more recent study at $140^{\circ} \mathrm{W}$.

Since the $f$-ratios were consistently low in the equatorial Pacific region, the implication is that the food web structure is more like that of oligotrophic subtropical regions than coastal upwelling areas (Murray et al. 1989). This is consistent with observations of phytoplankton standing stock, as measured by chl $a$, which remained low despite the production values (Walsh 1976, Peña et al. 1990, Cullen et al. 1992); thus, consideration of standing stock and rate of growth alone suggest a tight coupling between phytoplankton cells and grazers. The existence of a regenerationbased system implies a more complex microbial food web leading to macrozooplankton than one based on new nutrients. In the equatorial Pacific at $150^{\circ} \mathrm{W}$, Eppley \& Renger (1992) found $\mathrm{NO}_{3}{ }^{-}$utilization rates that exceeded the rates of $\mathrm{NO}_{3}^{-}$incorporation into particulate matter leading them to speculate that the production of dissolved organic matter is significant

Table 3. Comparison of nutrient concentration, chl a and hourly rates of primary productivity and nitrogen uptake integrated over the euphotic zone in the equatorial Pacific region. Mean values (standard deviation)

\begin{tabular}{|c|c|c|c|}
\hline & $\begin{array}{c}\sim 85^{\circ} \mathrm{W} \\
\text { (Murray et al. 1989) }\end{array}$ & $\begin{array}{c}135^{\circ} \mathrm{W} \\
\text { (present study) }\end{array}$ & $\begin{array}{c}150^{\circ} \mathrm{W} \\
\text { (Dugdale et al. 1992) }\end{array}$ \\
\hline Nitrate $\left(\mathrm{mmol} \mathrm{m}^{-3}\right)$ & $9.4(1.3)$ & $4.8(0.3)$ & 5 \\
\hline Ammonium (mmol $\left.\mathrm{m}^{-3}\right)$ & $0.7(0.5)$ & $\mathrm{n} / \mathrm{a}$ & 0.2 \\
\hline $\mathrm{Chl} a\left(\mathrm{mg} \mathrm{m}^{-2}\right)$ & $32.0(2.4)$ & $25.2(2.1)$ & $\mathrm{n} / \mathrm{a}$ \\
\hline $\mathrm{NO}_{3}^{-}$uptake (mmol $\left.\mathrm{N} \mathrm{m}^{-2} \mathrm{~h}^{-1}\right)$ & $0.184(0.01)$ & $0.105(0.03)$ & $0.102(0.03)$ \\
\hline $\mathrm{NH}_{4}^{+}$uptake (mmol $\left.\mathrm{N} \mathrm{m}^{-2} \mathrm{~h}^{-1}\right)$ & $0.273(0.04)$ & $0.045-0.483(0.03-0.29)$ & $0.351(0.10)$ \\
\hline Primary productivity $\left(\mathrm{mg} \mathrm{C} \mathrm{m}{ }^{-2} \mathrm{~h}^{-1}\right)$ & $32.2(2.1)$ & $54.2(26.5)$ & $55.7(4.3)$ \\
\hline$f$-ratio ${ }^{a}$ & 0.4 & $0.7-0.18$ & 0.22 \\
\hline$f$-ratio ${ }^{b}$ & 0.44 & 0.15 & 0.14 \\
\hline \multicolumn{4}{|c|}{$\begin{array}{l}{ }^{a} f \text {-ratio }=\mathrm{NO}_{3}{ }^{-} \text {uptake } /\left(\mathrm{NO}_{3}{ }^{-} \text {and } \mathrm{NH}_{4}{ }^{+}\right) \text {uptake } \\
{ }^{b} f \text {-ratio }=\left(\mathrm{NO}_{3}{ }^{-} \text {uptake } \times 6.6\right) / \text { primary productivity } \\
\text { n/a: no data available }\end{array}$} \\
\hline
\end{tabular}


and that this could be an expression of an active microbial food web. The occurrence of high grazing pressure in the equatorial region will increase the availability of regenerated $\mathrm{N}$ and reduce the absolute consumption of $\mathrm{N}$ by reduction in the phytoplankton biomass.

Because $\mathrm{NH}_{4}^{+}$concentrations were not measured in our study, accurate determination of the rates of regenerated production was not possible. However, there are some comments we can make based on our estimated range of $\mathrm{NH}_{4}{ }^{+}$uptake rates. First, the $\mathrm{NH}_{4}{ }^{+}$ concentration in the equatorial region cannot be as low as that observed in the oligotrophic ocean (Sargasso Sea) if the $f$-ratio computed using total ${ }^{15} \mathrm{~N}$ is similar to that estimated using total production as ${ }^{14} \mathrm{C}$ uptake (Dugdale et al. 1992). This is consistent with recent measurements of $\mathrm{NH}_{4}{ }^{+}$concentration in the central equatorial Pacific region where 0.1 to $0.3 \mathrm{mmol} \mathrm{m}^{-3}$ of $\mathrm{NH}_{4}{ }^{+}$were found (Wilkerson \& Dugdale 1992). Alternatively, the uptake of other regenerated $N$ forms (i.e. urea) could be contributing considerably to total $N$ uptake.

Several laboratory and field studies in marine systems have shown that phytoplankton prefer $\mathrm{NH}_{4}^{+}$ over other forms of $\mathrm{N}$ (Conway 1977. McCarthy et al. 1977, Syrett 1981, Glibert et al. 1982b). The physiological basis for this preference seems to be the greater energetic costs associated with the transport, reduction, and assimilation of $\mathrm{NO}_{3}{ }^{-}$. However, Thompson et al. (1989) found that any advantage that may be gained due to the lower energetic cost of growth on $\mathrm{NH}_{4}{ }^{+}$ would be restricted to situations involving high photon flux density (and no other limiting substrate). At low photon flux density, there would be no clear advantage, in terms of growth rate, to the use of $\mathrm{NH}_{4}{ }^{+}$over $\mathrm{NO}_{3}{ }^{-}$. It has been suggested that the presence of $\mathrm{NH}_{4}{ }^{+}$ may substantially inhibit the uptake of $\mathrm{NO}_{3}^{-}$by phytoplankton (McCarthy 1981, Wheeler \& Kokkinakis 1990). Although the evidence for $\mathrm{NH}_{4}{ }^{+}$inhibition in the field has been lately questioned (Dortch 1990, Price et al. 1991), the preference for $\mathrm{NH}_{4}^{+}$uptake over other $\mathrm{N}$ forms is still widely accepted.

Most of the research on N physiology of phytoplankton has focussed on diatoms. There is little information about the physiology of small phytoplankton cells that tend to dominate in open ocean systems, although some studies suggest that this physiology may differ considerably. For example. Probyn et al. (1990) found nanoplankton and picoplankton activity continued almost unchanged during the dark while net plankton activity declined markedly. Also, it has been suggested that large diatoms show a preference for growth on $\mathrm{NO}_{3}{ }^{-}$(Malone 1980), while $\mathrm{NH}_{4}{ }^{+}$is preferred by small phytoplankton (e.g. Nalewajko \& Garside 1983, Probyn 1985, Harrison \& Wood 1988).
In several regions, it has been observed that $\mathrm{NO}_{3}{ }^{-}$ uptake rates are higher near the base of the euphotic zone than in the surface layer (Conway \& Whitledge 1979, Nelson \& Conway 1979, Priscu 1984, Lewis et al. 1986). This pattern is generally thought to reflect the increase in $\mathrm{NO}_{3}{ }^{-}$availability within the subsurface nutricline region. $\mathrm{NO}_{3}{ }^{-}$uptake rates in the present study increased with depth at the stations where $\mathrm{NO}_{3}{ }^{-}$concentration increased. This was also evident in the equatorial Pacific region where $\mathrm{NO}_{3}^{-}$was abundant throughout the euphotic zone. Since $\mathrm{NO}_{3}{ }^{-}$uptake rates generally saturate at lower $\mathrm{NO}_{3}{ }^{-}$concentrations than those observed in the equatorial region (e.g. Maclsaac \& Dugdale 1969), the increase in $\mathrm{NO}_{3}{ }^{-}$uptake must have been influenced by factors other than changes in $\mathrm{NO}_{3}{ }^{-}$availability, e.g. changes in the interaction between $\mathrm{NO}_{3}{ }^{-}$and $\mathrm{NH}_{4}{ }^{+}$uptake responding to lowering irradiance as discussed previously. In the equatorial Pacific region at $150^{\circ} \mathrm{W}$, the concentration of $\mathrm{NO}_{3}{ }^{-}$, as well as its uptake rates, remained uniform throughout the euphotic zone (Dugdale et al. 1992). Thus, along the equatorial Pacific region vertical variations in $\mathrm{NO}_{3}^{-}$ uptake rates appear to follow longitudinal variations in the depth of the nitracline (Barber \& Chavez 1992).

The increase in $\mathrm{NO}_{3}{ }^{-}$uptake with depth observed here was not paralleled by an increase in $\mathrm{C}$ uptake. This uncoupling in the vertical has often been observed (e.g. McCarthy \& Nevins 1986) and values integrated over the euphotic zone rather than at particular depths are more relevant when considering biochemical ratios. In the regions we investigated where the mixed layer is much shallower than the euphotic zone, the balance between $N$ and $C$ uptake by phytoplankton cells was not evident. It could be argued that the uptake and assimilation of $\mathrm{N}$ is frequently uncoupled, and that a significant fraction of $\mathrm{N}$ taken up by phytoplankton cells is released as dissolved organic or inorganic $\mathrm{N}$. This may be particularly true when small cells that presumably have a low capacity to store nutrients are dominant, as in the equatorial region. The availability of DON could, in turn, stimulate $\mathrm{NH}_{4}{ }^{+}$regeneration by heterotrophic bacteria (Kirchman et al. 1989), increasing its availability for phytoplankton utilization. Alternatively, the uptake of $\mathrm{NO}_{3}{ }^{-}$may be due in part to non-photosynthetic organisms as suggested by Eppley \& Renger (1992). In our study, a clear relationship between chl a and $\mathrm{NO}_{3}$ uptake was not observed, therefore we cannot exclude the possibility that heterotrophic $\mathrm{NO}_{3}{ }^{-}$uptake may have been important.

In most oceanic regions, $\mathrm{N}$ availability is thought to limit phytoplankton production (e.g. Dugdale 1967). In these nutrient limited systems, $\mathrm{NO}_{3}{ }^{-}$flux to the euphotic zone sets the upper limit on new production such that new production and the $f$-ratio may be 
derived of ambient $\mathrm{NO}_{3}{ }^{-}$concentration or primary productivity level (Eppley \& Peterson 1979, Platt \& Harrison 1985, Harrison et al. 1987). In contrast, in the equatorial Pacific region where $\mathrm{NO}_{3}^{-}$is abundant, estimates of new production rates based on these relationships significantly overestimate the measured values (Dugdale et al. 1992). In this region, as in other oceanic regions where $\mathrm{NO}_{3}$ is abundant, the availability of regenerated $N$ (Glibert et al. 1982b, Wheeler \& Kokkinakis 1990) or the absence of trace metals (Price et al. 1991) ultimately may set the limit on the uptake of $\mathrm{NO}_{3}^{-}$.

Our results indicate, as others have, that the most abundant $\mathrm{N}$ form is not necessarily the most important in the nutrition of the phytoplankton. In the equatorial Pacific region, since phytoplankton meet most of their growth requirement for $\mathrm{N}$ from regenerated sources (i.e. $\mathrm{NH}_{4}{ }^{+}$), it is not surprising that $\mathrm{NO}_{3}{ }^{-}$concentrations remain high. It is unclear, however, how spatial and temporal variations in $\mathrm{NO}_{3}{ }^{-}$and $\mathrm{NH}_{4}{ }^{+}$concentration may affect the rate of new production. Although few studies of $\mathrm{N}$ uptake have been done in the equatorial Pacific region to date, it is clear that more information will be needed on the interactions between the different $\mathrm{N}$ forms and on the importance of other growth substances (e.g. Fe) to phytoplankton $N$ nutrition before efforts to model new production will progress further.

Acknowledgements. We thank D. Barber, R. Palmer, S. McLean and the crew of the RV 'Wecoma' for assistance at sea. We also thank $J$. Cullen for critically reading an earlier version of this manuscript. This research was supported by the National Science and Engineering Research Council, Strategic Grant Program (Canada).

\section{LITERATURE CITED}

Barber, R. T., Chavez, F. P. (1991). Regulation of primary productivity rate in the equatorial Pacific Ocean. Limnol. Oceanogr. (in press)

Brzezinski, M. A. (1988). Vertical distribution of ammonjum in stratified oligotrophic waters. Limnol. Oceanogr. 33: $1176-1182$

Chavez, F. P., Barber, R. T (1987). An estimate of new production in the equatorial Pacific. Deep Sea Res. 34: $1229-1243$

Chavez, F. P. (1989). Size distribution of phytoplankton in the central and eastern tropical Pacific. Global Biochem. Cycles 3: 27-35

Cochlan, W. P., Price, N. M., Harrison, P. J. (1991). Effects of irradiance on nitrogen uptake by phytoplankton: comparison of frontal and stratified communities. Mar. Ecol Prog. Ser. 69: 103-116

Conway, H. L. (1977). Interactions of inorganic nitrogen in the uptake and assimilation by marine phytoplankton. Mar. Biol. 39: 221-232

Conway, H. L., Whitledge T. E. (1979). Distribution, fluxes and biological utilization of inorganic nitrogen during a spring bloom in the New York Bight. J. mar. Res. 37: 657-668

Cromwell, T (1953). Circulation in a meridional plane in the central equatorial Pacific. J. mar. Res. 12: 196-213

Cullen, J. J., Lewis, M. R., Davis, C. O., Barber, R. T (1992). Photosynthetic characteristics and estimated growth rates indicate grazing is the proximate control of primary production in the equatorial Pacific. J. geophys. Res. 97 : $639-654$

Dortch, Q. (1990). The interaction between ammonium and nitrate uptake in phytoplankton. Mar. Ecol. Prog. Ser. 61. $183-201$

Dugdale, R. C. (1967). Nutrient limitation in the sea: dynamics, identification, and significance. Limnol. Oceanogr. 12: 685-695

Dugdale, R. C., Goering, J. J. (1967). Uptake of new and regenerated forms of nitrogen in primary productivity. Limnol. Oceanogr 12: 196-206

Dugdale, R. C., Wilkerson, F. P. (1986). The use of ${ }^{15} \mathrm{~N}$ to measure nitrogen uptake in eutrophic oceans: experimental considerations. Limnol. Oceanogr. 31: 673-689

Dugdale, R. C., Wilkerson, F. P., Barber, R. T., Chavez, F. P. (1992). Estimating new production in the equatorial Pacific Ocean at $150^{\circ} \mathrm{W}$. J. geophys. Res. 97: 681-686

Eppley, R. W., Peterson, B. J. (1979). Particulate organic matter flux and planktonic new production in the deep ocean. Nature, Lond. 282:677-680

Eppley, R. W., Renger, E. H. (1992). Nitrate utilization by plankton in the equatorial Pacific, March 1988 along $150^{\circ}$ W. J. geophys. Res. 97: 663-668

Eppley, R. W., Chavez, F. P., Barber, R. T (1992). Standing stocks of particulate carbon and nitrogen in the equatorial Pacific at $150^{\circ} \mathrm{W}$. J. geophys. Res. 97: 655-661

Fieldler, R., Proksch, G. (1975). The determination of nitrogen- 15 by emission and mass spectrometry in biochemical analysis: a review. Analytica Chim. Acta 78:1-62

Garside, C. (1991). Shift-up and the nitrate kinetics of phytoplankton in upwelling systems. Limnol. Oceanogr 36 $1239-1244$

Glibert, P. M., Lipschultz, F., McCarthy, J. J., Altabet, M. A. (1982a). Isotope dilution models of uptake and remineralization of ammonium by marine plankton. Limnol. Oceanogr. 27: 639-650

Glibert, P. M., Biggs, D. C., McCarthy, J. J. (1982b). Utilization of ammonium and nitrate during austral summer in the Scotia Sea. Deep Sea Res. 29: 837-850

Harrison, W. G. (1983). Nitrogen in the marine environment IV.2 Use of isotopes. In: Carpenter, E J., Capone, D. G. (eds.) Nitrogen in the marine environment. Academic Press, New York, p. 763-807

Harrison, W. G., Platt, T., Lewis, M. R. (1987). f-Ratio and its relationship to ambient nitrate concentration in coastal waters. J. Plankton Res. 9: 235-248

Harrison, W. G., Wood, L. J. E. (1988). Inorganic nitrogen uptake by marine picoplankton: evidence for size partitioning. Limnol. Oceanogr. 33: 468-475

Harrison, W. G., Harris, L.R., Karl, D. M., Knauer, G. A. Redalje, D. G. (1992). Nitrogen dynamics at the VERTEX time-series site. Deep Sea Res. (in press)

Holm-Hansen, O., Lorenzen, C. J., Holmes, R. W., Strickland, J. D. H. (1965). Fluorometric determination of chlorophyll J. Cons. perm. int. Explor. Mer 30: 3-15

Kanda, J., Laws, E., Saino, T., Hattori, A. (1987). An evaluation of isotope dilution effects from conventional data sets of $15 \mathrm{~N}$ uptake experiments. J. Plankton Res. 9: 79-90

Kirchman, D. L., Keil, R. G., Wheeler, P. A. (1989). The effect of amino acids on ammonium utilization and regeneration 
by heterotrophic bacteria in the subarctic Pacific Deep Sea Res. 36: 1763-1776

Knauss, J. A. (1963). Equatorial current systems. In: Hill, M. N. (ed.) The sea, Vol. 2. Interscience., London, p. 235-252 Lewis, M. R., Harrison, W. G., Oakey, N. S., Hebert, D., Platt, $T$ (1986). Vertical nitrate fluxes in the oligotrophic ocean. Science 234: 870 -873

MacIsaac, J. J., Dugdale, R. C. (1969). The kinetics of nitrate and ammonia uptake by natural populations of marine phytoplankton. Deep Sea Res. 16: 45-57

Maclsaac, J. J., Dugdale, R. C. (1972). Interactions of light and inorganic nitrogen in controlling nitrogen uptake in the sea. Deep Sea Res. 19: 209-232

Maclsaac, J. J., Dugadale, R. C., Barber, R. T., Blasco, D., Packard, T. T. (1985). Primary production cycle in an upwelling center. Deep Sea Res. 32: 503-522

Malone, T C. (1980). Algal size. In: Morris, I. (ed.) The physiological ecology of phytoplankton. Blackwell, London, p. 433-464

Martin. J. H., Gordon, R. M., Fitzwater, S., Broenkow, W. W. (1989). VERTEX: phytoplankton/iron studies in the Gulf of Alaska. Deep Sea Res. 36: 649-680

McCarthy, J. J., Taylor, W. R., Taft, J. L. (1977). Nitrogenous nutrition of the plankton in the Chesapeake Bay. I. Nutrient availability and phytoplankton preferences. Limnol. Oceanogr. 22: 996-1011

McCarthy, J. J. (1981). The kinetics of nutrient utilization, Can. Bull. Fish. Aquat. Sci. 210: 211-233

McCarthy, J. J. Nevins, J. L. (1986). Sources of nitrogen for primary production in warm-core rings $79-\mathrm{E}$ and $81-\mathrm{D}$. Limnol. Oceanogr. 31: 690-700

Minas, H. J., Minas, M., Packard, T. T (1986). Productivity in upwelling areas deduced from hydrographic and chemical fields. Limnol. Oceanogr. 31: 1182-1206

Murray, J W., Downs, J N., Strom, S., Wei, C. L., Jannasch, $H$. W. (1989). Nutrient assimilation, export production and ${ }^{234}$ Th scavenging in the eastern equatorial Pacific. Deep Sea Res. 36: 1471-1489

Nalewajko, C., Garside, C. (1983). Methodological problems in the simultaneous assessment of photosynthesis and nutrient uptake in phytoplankton as functions of light intensity and cell size. Limnol. Oceanogr. 28: 591-597

Nelson, D. M. Conway, H. L. (1979). Effects of the light regime on nutrient assimilation by phytoplankton in the Baja California and northwest Africa upwelling systems. J. mar. Res. 37: 301-318

Peña, M. A., Lewis, M. R., Harrison, W. G. (1990). Primary productivity and size structure of phytoplankton biomass on a transect of the equator at $135^{\circ} \mathrm{W}$ in the Pacific Ocean. Deep Sea Res. 37: 295-315

Peña, M. A., Lewis, M. R., Harrison, W.G. (1991). Particulate organic matter and chlorophyll in the surface layer of the equatorial Pacific Ocean along $135^{\circ}$ W. Mar. Ecol. Prog. Ser. 72: $179-188$

This article was submitted to the editor
Platt, T., Harrison, W. G. (1985). Biogenic fluxes of carbon and oxygen in the ocean. Nature, Lond. 318: 55-58

Price, N. M., Harrison, P. J., Landry, M. R., Azam, F, Hall, K. J. F. (1986). Toxic effects of latex and Tygon tubing on marine phytoplankton, zooplankton and bacteria. Mar. Ecol. Prog. Ser. 34: 41-49

Price, N. M., Andersen, L. F., Morel, F. M. M. (1991). Iron and nitrogen nutrition of equatorial Pacific plankton. Deep Sea Res. 38: 1361-1378

Priscu, J. C. (1984). A comparison of nitrogen and carbon assimilation in the shallow and deep-water phytoplankton populations of a subalpine lake: response to photosynthetic photon flux density. J. Plankton Res. 6: $733-749$

Probyn, T A. (1985). Nitrogen uptake by size-fractionated phytoplankton populations in the southern Benguela upwelling system. Mar. Ecol. Prog. Ser. 22: 249-258

Probyn, T A., Waldron, H. N., James, A. G. (1990). Sizefractionated measurements of nitrogen uptake in aged upwelled waters: Implications for pelagic food webs. Limnol. Oceanogr. 35: 202-210

Steemann Nielsen, E. (1952). The use of radioactive carbon $\left({ }^{14} \mathrm{C}\right)$ for measuring organic production in the sea. J. Cons. perm, int. Explor. Mer 18: 117-140

Steemann Nielsen, E., Hansen, V. K. (1959). Measurements with the ${ }^{14} \mathrm{C}$ technique of the respiration rates in natural populations of phytoplankton. Deep Sea Res. 5: $222-232$

Strickland, J. D. H., Parsons, T R. (1972). A practical handbook of sea water analysis. Bull. Fish. Res. Bd Can. 167: $1-311$

Syrett, P. J. (1981). Nitrogen metabolism of microalgae, Can. Bull. Fish. Aquat. Sci. 210: 182-210

Thompson, P. A., Levasseur, M. E., Harrison, P. J. (1989). Light-limited growth on ammonium vs. nitrate: What is the advantage for marine phytoplankton?. Limnol. Oceanogr. 34: $1014-1024$

Thomas, W. H. (1979). Anomalous nutrient chlorophyll interrelationships in the offshore eastern tropical Pacific Ocean. J. mar. Res. 37: 327-335

Walsh, J. J. (1976). Herbivory as a factor in patterns of nutrient utilization in the sea. Limnol. Oceanogr. 21: 1-13

Wheeler, P. A., Kokkinakis, S. A. (1990). Anmonium recycling limits nitrate use in the oceanic subarctic Pacific. Limnol. Oceanogr. 35: 1267-1278

Wilkerson, F. P., Dugdale, R. C. (1987). The use of large shipboard barrels and drifters to study the effects of coastal upwelling on phytoplankton nutrient dynamics. Limnol. Oceanogr. 32: 368-382

Wilkerson, F. P., Dugdale, R. C. (1992). Measurements of nitrogen productivity in the equatorial Pacific. J. geophys. Res. 97: 669-679

Wyrtki, K. (1981). An estimate of equatorial upwelling in the Pacific. J. phys. Oceanogr. 11: 1205-1214

Manuscript first received: August 9, 1991

Revised version accepted: January 22, 1992 